\title{
THREE NEW ANDEAN SPECIES OF HYMENOPHYLLUM (HYMENOPHYLLACEAE-PTERIDOPHYTA)
}

\author{
MICHAEL KESSLER ${ }^{1}$, ALAN R. SMITH $^{2} \&$ MICHAEL SUNDUE ${ }^{3}$
}

\begin{abstract}
SUMMARY
We describe Hymenophyllum apteryx M. Kessler \& Sundue, H. assurgens M. Kessler \& A.R. Sm. and $H$. latisorum M. Kessler \& A.R. Sm. as new to science.
\end{abstract}

Key words: Hymenophyllum, Bolivia, Andes.

\section{INTRODUCTION}

During our studies of Bolivian ferns we have encountered three unnamed species of Hymenophyllum (Hymenophyllaceae, Pteridophyta) that are described here. With about 300 species in the genus, a limited range of morphological characters and marked morphological plasticity within species, the delimitation of species is notably difficult in Hymenophyllum (Morton, 1947; Tryon \& Stolze, 1989). For example, in his monograph of Hymenophyllum sect. Sphaerocionium, Morton (1947) admitted that all of the species in the complex of $H$. interruptum could be treated as one large and variable taxon; nonetheless, he adopted relatively narrow species concepts. We follow this course, as in addition to morphological differences, the taxa are usually also distinct biogeographically and ecologically. For convenience, we place the new species in Morton's (1968) classification system of the Hymenophyllaceae, even though recent molecular studies have shown the para- or polyphyly of some of Morton's entities (Hennequin et al., 2003). Morphological terms follow Lellinger (2002).

\section{DESCRIPTION OF SPECIES}

\section{Hymenophyllum apteryx M. Kessler \& Sundue, spec. nov. - Fig. 1a, b}

Differt a Hymenophyllum interrupto (Sw.) Sw. rhachidibus non alatis. - Typus: Sundue, Nee \& Carrasco 646 (holo USZ; iso LPB, NY, UC), Bolivia, Depto. Cochabamba, Prov. Carrasco, near pond along road from Cochabamba to Comarapa, $5.5 \mathrm{~km}$ E of El Churro, $17^{\circ} 50^{\prime} 27^{\prime \prime} \mathrm{S}, 64^{\circ} 44^{\prime} \mathrm{W}, 2975 \mathrm{~m}$.

Plants epiphytic, pendent; rhizomes $0.3-0.4 \mathrm{~mm}$ wide, sparsely pubescent, rhizome hairs $0.6-0.9 \mathrm{~mm}$ long, simple, multicellular. Leaves $13-34$ by $1.5-5 \mathrm{~cm}$, seemingly of

1) Albrecht-von-Haller-Institut für Pflanzenwissenschaften, Abteilung für Systematische Botanik, Untere Karspüle 2, D-37073 Göttingen, Germany; e-mail: mkessle2@gwdg.de.

2) University Herbarium, 1001 Valley Life Sciences Bldg. \#2465, University of California, Berkeley, CA 94720-2465, USA.

3) The New York Botanical Garden, Bronx, NY 10458-5126, USA. 

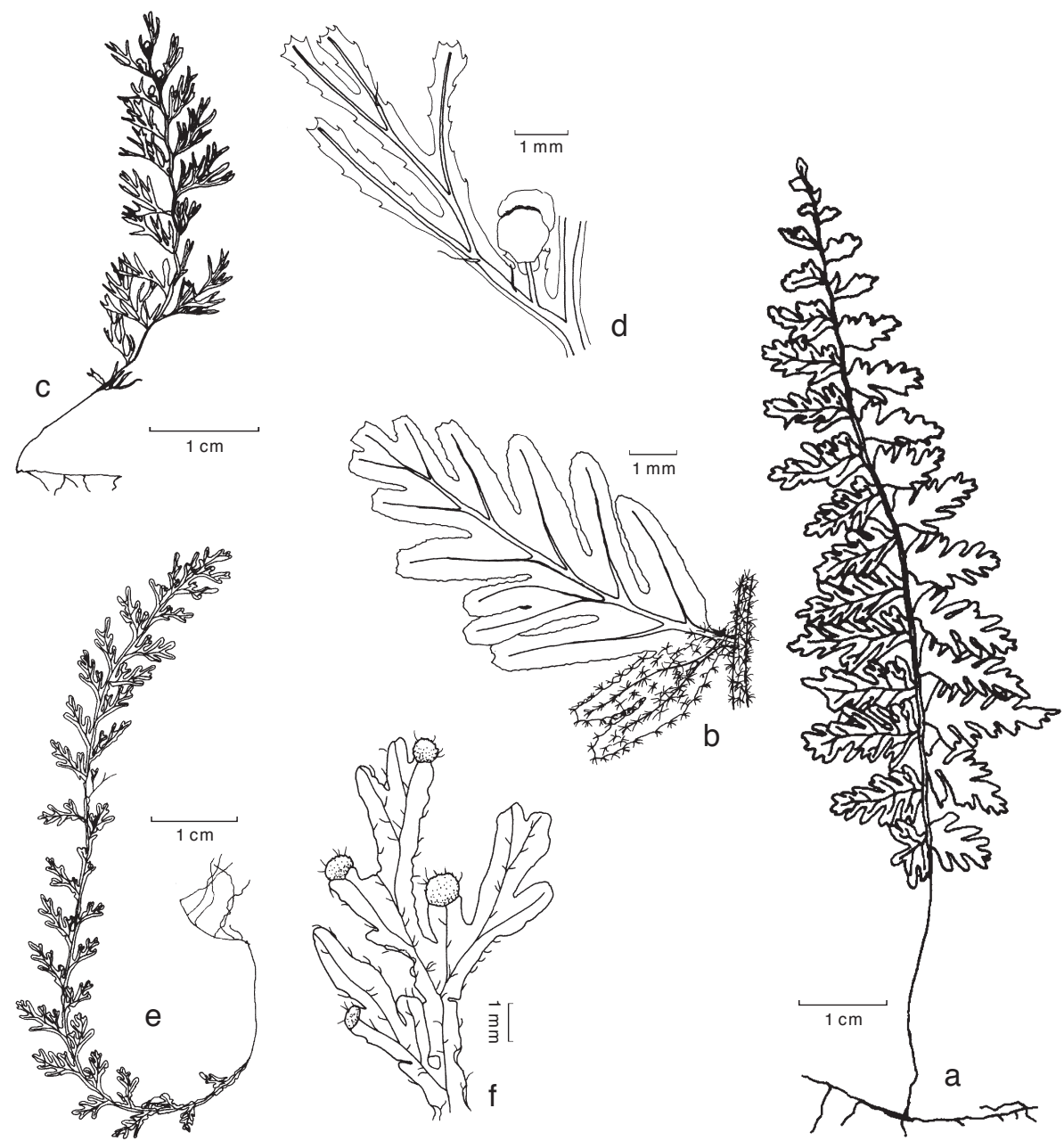

Fig. 1. a \& b: Hymenophyllum apteryx M. Kessler \& Sundue. a. Habit; b. pinna. — c \& d: H. assurgens M. Kessler \& A.R. Sm. c. Habit; d. pinna detail. — e \& f: H. latisorum M. Kessler \& A.R. Sm. e. Habit; f. pinna detail (a, b: Jimenez 923; c, d: Kessler 6705; e, f: Kessler 6552).

indeterminate apical growth, spaced $1-3 \mathrm{~cm}$ apart along the rhizomes; stipes $0.5-9.5 \mathrm{~cm}$ long, $0.3-0.5 \mathrm{~mm}$ wide, dark brown, sparsely to moderately pubescent, hairs $0.4-1 \mathrm{~mm}$ long, tan, multicellular, simple or stalked-stellate; rachises non-alate, densely pubescent, hairs light to dark reddish, 0.4-1.5 mm long, septate, simple or stalked-stellate; blades 1-pinnate-pinnatifid, oblong to elliptic, apically acute, basally attenuate with several pairs of reduced pinnae; pinnae 16-34 pairs, (8-)19-25 by (5-) $8-10 \mathrm{~mm}$, spreading or ascending, elliptic, sessile, basally truncate, apically rounded to acute, basal pinnae reduced to c. $5 \mathrm{~mm}$ long; pinna segments $0.6-1 \mathrm{~mm}$ wide, elliptic, in pairs, apically rounded, marginally serrulate, each tooth bearing a hair, hairs $0.3-0.5 \mathrm{~mm}$ long, simple, 
multicellular, forked, or stalked-stellate, light to dark reddish; abaxial and adaxial lamina surfaces moderately pubescent, not obscured by the presence of hairs, light to dark reddish hairs present along the veins, segment margins and on the laminar tissue between the veins, $0.3-1 \mathrm{~mm}$ long, multicellular, stalked-stellate. Indusia $0.8-1.4 \mathrm{~mm}$ wide, not or only slightly, wider than long, terminal on pinna lobes, margins of the involucres rounded, pubescent, hairs similar to those of the lamina surfaces; spores tetrahedral-globose, green.

Distribution - Andes of Bolivia. Probably also in Peru, where Tryon \& Stolze (1989: 72) mention specimens of H. plumieri Hook. \& Grev. (which they considered to include $H$. interruptum) with unwinged rachises.

Ecology - Locally common epiphyte in humid cloud forests with Brachyotum, Podocarpus, Sphagnum, and Weinmannia at 2200-3250 m.

Notes - Hymenophyllum apteryx belongs to subgenus Sphaerocionium in which it is referable to a group of species that includes $H$. dependens $\mathrm{C}$.V. Morton, $H$. interruptum Kunze, H. plumieri Hook. \& Grev., H. sieberi (C. Presl) Bosch, and H. superbum C.V. Morton. It differs from all of those species, as the name suggests, by having non-alate rachises throughout their length, whereas the close relatives have rachises that are entirely alate or, in the case of $H$. interruptum, non-alate only at the very bases.

Hymenophyllum apteryx is most similar to $H$. interruptum, and although the observed difference between the two may seem slight, we find that where the range of $H$. interruptum overlaps that of $H$. apteryx, the two species grow together without any intermediates. The colour of the pubescence between the two species also differs, but can not always be used to distinguish the species. The hairs of $H$. apteryx are primarily light to dark reddish, those of $H$. interruptum are primarily castaneous, but some may be bicolorous, in which case some of the cells of the multicellular, stalked-stellate hairs are stramineous while others are castaneous. Hymenophyllum apteryx also has a tendency towards denser, shorter, and more short-stalked hairs as well as shorter, more curved pinnae and pinnules than $H$. interruptum, but there is ample overlap between the species in these characteristics. Both species also appear to be separated elevationally. While $H$. interruptum occurs mostly between 1300 and $2600 \mathrm{~m}$, with a few collections made up to $3000 \mathrm{~m}$ (mean elevation of 60 Bolivian collections: $1920 \mathrm{~m}$ ), the 14 collections of $H$. apteryx known to us were made between 2200 and $3250 \mathrm{~m}$ (mean elevation: $2700 \mathrm{~m}$ ). All of the specimens we recognize as H. apteryx have been recently collected, since Morton's (1947) monograph.

Additional material examined:

Arbelaez 857 (USZ); Arroyo 66 pp (LPB, UC); Fay \& Fay 2407 (LPB, MO, UC); Jimenez 920 (LPB); Jimenez 923 (GOET, LPB, UC); Jimenez 1892 (GOET, LPB, UC); Kessler 6811 (LPB, UC); Kessler 7054 (LPB, UC); Kessler 9044b (LPB, UC); Núñez 482 (NY); Núñez 651 (NY).

2. Hymenophyllum assurgens M. Kessler \& A.R. Sm., spec. nov. - Fig. 1c, d

Differt a Hymenophyllum tunbrigensi (L.) J. Sm. marginis indusiorum integribus vel paulo dentatis (vs dentatis vel undulatis) segmentisque angustioribus (0.4-0.6 vs $0.7-0.9 \mathrm{~mm}$ latis) magis ascendentibus. - Typus: Kessler 6705 (holo UC; iso GOET, LPB), Bolivia, Depto. Cochabamba, Prov. Carrasco, 107 km antigua carretera Cochabamba-Villa Tunari, $17^{\circ} 10^{\prime} \mathrm{S}, 65^{\circ} 38^{\prime} \mathrm{W}, 3050 \mathrm{~m}$. 
Plants epiphytic or saxicolous; rhizomes c. $0.2 \mathrm{~mm}$ wide, filiform, long-creeping. Leaves to $9 \mathrm{~cm}$ long, broadly to narrowly lanceolate; petioles to $3 \mathrm{~cm}$ by $0.4 \mathrm{~mm}$, unwinged, glabrous; blades 1-pinnate-pinnatisect, membranaceous, longest pinnae in the middle or lower third of the blades; rachises dark brown, distally narrowly winged, glabrous or sparsely pubescent, hairs $0.2-0.5 \mathrm{~mm}$ long, reddish brown, simple; pinnae to 15 by 7 $\mathrm{mm}$, placed $65-80^{\circ}$ to the rachises, segments $0.4-0.6 \mathrm{~mm}$ wide, glabrous or sparsely pubescent on the veins, hairs similar to those on the rachises, margins serrulate. Indusia ovate, to 1.2 by $1 \mathrm{~mm}$, broader than the subtending segments, 1-2(-4) per pinna on the basalmost acroscopic (and sometimes basiscopic) pinnules, arcuate (curved out of the plane of the blade), margins subentire to irregularly serrulate, receptacles sometimes exserted at maturity; spores tetrahedral-globose, green.

Distribution - Andes of Bolivia and Venezuela, probably also elsewhere in the tropical Andes.

Ecology - Locally common epiphytic and saxicolous species in humid cloud forests at $2500-3050 \mathrm{~m}$.

Note - With its small size, serrulate segment margins, and indusia arched out of the plane of the blade, this species belongs to the H.tunbrigense (L.) J. Sm. species group in subgenus Hymenophyllum. Hymenophyllum assurgens differs from $H$. tunbrigense by its entire to only slightly dentate (vs dentate to undulate) indusial margins, and narrower $(0.4-0.6 \mathrm{~mm}$ vs $0.7-0.9 \mathrm{~mm})$, more strongly ascending segments. It is also related to $H$. peltatum (Poir.) Desv., from which it is distinguished by its narrower, more strongly ascending segments and by the reddish brown (vs whitish) hairs on the rachises and veins. The elevational ranges of the three species in Bolivia are $2500-3050 \mathrm{~m}$ (mean $2833 \mathrm{~m}$ ) for H. assurgens, 1860-3600 m (mean $2581 \mathrm{~m}$ ) for H. tunbrigense, and 2400-4550 m (mean $3287 \mathrm{~m}$ ) for H. peltatum. Hymenophyllum assurgens belongs to a taxonomically difficult species group that is in need of a worldwide revision; many Andean specimens of this group have been misidentified in herbaria.

Additional material examined:

Bolivia. Kessler 6631 (LPB); Kessler 10509 (GOET, LPB, UC). VENEZUELA. Luteyn \& Cotton 9686 (NY, UC); Luteyn \& Cotton 9687 (NY, UC).

\section{Hymenophyllum latisorum M. Kessler \& A.R. Sm., spec. nov. - Fig. 1e, f}

\footnotetext{
Species subgeneris Sphaerocionii involucris latioribus quam longioribus marginum pilosarum, pilis simplicibus marginum segmentorum, alis rhachidis undulatis. - Typus: Kessler 6552 (holo UC; iso GOET, LPB), Bolivia, Depto. Cochabamba, Prov. Carrasco, 108 km antigua carretera Cochabamba-Villa Tunari, $17^{\circ} 09^{\prime} \mathrm{S}, 65^{\circ} 38^{\prime} \mathrm{W}, 2950 \mathrm{~m}$.
}

Plants epiphytic; rhizomes $0.2-0.3 \mathrm{~mm}$ wide, filiform, long-creeping. Leaves erect to arching, to $15 \mathrm{~cm}$ long, lanceolate; petioles to $5.5 \mathrm{~cm}$ by $0.4 \mathrm{~mm}$, alate in the distal half, wings undulate, glabrous to very slightly pubescent with spreading, brown, unbranched hairs $0.4-0.8 \mathrm{~mm}$ long; blades 1-pinnate-pinnatisect to almost 2-pinnate, membranaceous, longest pinnae usually the 2nd to 4th pairs; rachises dark brown, alate, wings $0.5-1 \mathrm{~mm}$ wide, undulate, slightly pubescent with spreading, pale brown, stalked, simple or forked hairs $0.3-0.7 \mathrm{~mm}$ long, or hairs stellate with up to 4 rays; pinnae to 20 by $10 \mathrm{~mm}, 50-60^{\circ}$ to the rachises, the segments $0.8-1.7 \mathrm{~mm}$ wide, glabrous between the veins, on the veins with hairs similar to those of rachises, margins 
pubescent with the hyaline to light tan, spreading, simple, well-spaced hairs c. $0.4 \mathrm{~mm}$ long. Indusia rounded to broader than long, to 1.2 by $1.3 \mathrm{~mm}$, as broad as to slightly broader than the subtending segments, margins finely denticulate, bearing hyaline to light tan, simple or 1-forked hairs to $0.3 \mathrm{~mm}$ long; sporangia $12-20$ per sorus; spores tetrahedral-globose, green.

Distribution - Andes of central Bolivia.

Ecology - Epiphyte in humid cloud forests at 2050-2950 $\mathrm{m}$ in the departments of Cochabamba and Santa Cruz. At the type locality, H. latisorum was very common in a narrow elevational zone at 2800-2950 m.

Note - Hymenophyllum latisorum belongs to subgenus Sphaerocionium, among the species of which it is characterized by its very broad (often broader than long) involucres with hairy margins, simple hairs along the segment margins, and rachises with undulate wings. It is most similar to H. valvatum Hook. \& Grev., from which it differs by its broader and more densely hairy involucres and flat (vs undulate) segments. Whereas H. valvatum has been recorded at $900-2450 \mathrm{~m}, H$. latisorum has been collected at 2050-2950 m

Additional material examined:

Kessler 6394 (LPB, UC); Kessler 6557 (LPB, UC); Kessler 6632 (LPB, UC).

\section{ACKNOWLEDGEMENTS}

We thank Viktoria Wagner and Ana Moguel for rendering the illustrations and Marcus Lehnert for the Latin diagnoses. Kessler's field work in Bolivia and taxonomic work on Bolivian ferns is financially supported by the Deutsche Forschungsgemeinschaft, and would be impossible without the collaboration of the personnel of the Herbario Nacional de Bolivia, especially Dr. Stephan G. Beck and Iván Jimenez.

\section{REFERENCES}

Hennequin, S., A. Ebihara, I. Motomi, K. Iwatsuki \& J.-Y. Dubuisson. 2003. Molecular systematics of the fern genus Hymenophyllum s.l. (Hymenophyllaceae) based on chloroplastic coding and noncoding regions. Molec. Phylogenet. Evol. 27: 283-301.

Lellinger, D.B. 2002. A modern multilingual glossary for taxonomic pteridology. Pteridologia 3: $1-263$.

Morton, C.V. 1947. The American species of Hymenophyllum sect. Sphaerocionium. Contr. U.S. Natl. Herb. 29: 139-201.

Morton, C. V. 1968. The genera, subgenera, and sections of the Hymenophyllaceae. Contr. U.S. Natl. Herb. 38: $153-214$.

Tryon, R.M. \& R.G. Stolze. 1989. Pteridophyta of Peru. Part I. 1. Ophioglossaceae-12. Cyatheaceae. Fieldiana, Bot., n.s. 20: 1-145. 